2004

\title{
Rhetoric, Advocacy and Ethics: Reflections on Shakespeare's Julius Caesar
}

Stephen A. Newman

New York Law School, stephen.newman@nyls.edu

Follow this and additional works at: https://digitalcommons.nyls.edu/fac_articles_chapters

Part of the Legal Education Commons, Legal Profession Commons, and the Legal Writing and Research Commons

\section{Recommended Citation}

Newman, Stephen A., "Rhetoric, Advocacy and Ethics: Reflections on Shakespeare's Julius Caesar" (2004). Articles \& Chapters. 1160. https://digitalcommons.nyls.edu/fac_articles_chapters/1160 


\title{
RHETORIC, ADVOCACY, AND ETHICS: REFLECTIONS ON SHAKESPEARE'S JULIUS CAESAR
}

\author{
Stephen A. Newman \\ Professor of Law, New York Law School
}

Professionals generally learn their craft from those who have gone before them. Lawyers are initially trained by law professors, and then apprentice themselves to more experienced attorneys in practice. Critical professional skills are often acquired, improved and polished while on the job. But for some skills, lawyers can benefit considerably from looking outside the confines of the legal profession. The rhetorical skill necessary to speaking and writing persuasively, for example, a skill surely essential to the lawyer's craft ${ }^{1}$, may be studied with great profit by exploring realms of knowledge far from the courtroom and the law office.

${ }^{1}$ An illuminating discussion of the role of rhetoric in law and legal advocacy appears in Gerald Wetlaufer, "Rhetoric and its Denial in Legal Disocurse,” 76 Va. L.Rev. 1545 (1990). “[L]aw is the very profession of rhetoric. We are the sons and daughters of Gorgias himself.” Id. at 1554-55. Michael Frost links the ancient Greek and Roman rhetoricians to modern legal advocacy in “Ethos, Pathos and Legal Audience,” 99 Dick. L. Rev. 85 (1994). 
Literature naturally comes to mind as a rich resource for the study of persuasion. For this essay, I have chosen a well-known set of speeches that appear in William Shakespeare's Julius Caesar to illustrate the potential of this resource for lawyers and law students. In the play, Rome's greatest general meets with a violent and bloody death, not on the field of battle, but on his arrival at the Capitol in Rome on a seemingly ordinary day in March. The Romans in the play, and the theater audience watching, must confront a troubling question posed by the slaying: Is the assassination a crime of murder, a treasonous act by Caesar's political opponents, or is it a sacrifice justified by necessity, the only means available to prevent the death of the Roman republic at the hands of a would-be tyrant? In the play's most riveting scene, Marcus Brutus and Mark Antony speak before a crowd of Romans, giving their opposing views of the assassination of Caesar. Brutus claims justification for his and his co-conspirators' act; Antony presents the case for murder by traitors.

In this scene, Shakespeare has dramatized an occasion specifically calling upon two leading citizens to present persuasive, opposing statements of their positions on the most important issue of their time. The stakes could not be higher: the lives and fortunes of both speakers, and the fate of their country, depend upon their rhetorical skill. Can members of the legal profession, dedicated to the art of advocacy, fail to pay attention to such a rare rhetorical display-a gift fashioned by our greatest playwright some four centuries ago?

In reviewing each of these speeches, I will explore how Brutus and Antony advance their positions by adroitly employing many techniques of persuasion, including influencing the audience's membership; relying upon and strengthening their personal credibility; framing the crucial issue; creating a compelling theme; producing supporting evidence to substantiate the 
argument; meeting the audience's unstated emotional needs; minimizing adverse facts; monitoring audience reaction and assessing its understanding; achieving proper proportion in argument; speaking with civility; making concessions; distracting the audience; addressing preexisting audience opinions and knowledge; employing strong emotional appeals; using the power of suggestion; allowing the audience to reach its own conclusion; rebutting expected arguments of the opposition; and forging an effective rhetorical style.

All of these matters, taken together, illustrate the application of vital concepts in persuasion to the particular circumstances created by the play. Some shortcomings in the speeches are noted, particularly in the address by Brutus. I suggest there are times when Brutus may have diminished the force of his own presentation by allowing his personal attitudes and beliefs to interfere with his advocacy. I also raise ethical problems in considering the speech given by Antony. Any such faults, of course, should be attributed to the characters in the drama, and not to the playwright who put these extraordinary speeches on paper and gave us cause to wonder, as did Cassius, "How many ages hence / Shall this our lofty scene be acted over / In states unborn and accents yet unknown.”1

\section{The Speeches in Context}

In order to assess the persuasive quality of the two speeches, it is necessary to review the context in which they are delivered. Brutus is the leader of a group of conspirators who plot to kill Julius Caesar in order to prevent him from being crowned a king and imposing imperial rule, thereby destroying the Roman republic. The conspiracy has been organized by the wily and aggressive political operator Caius Cassius. Caesar has memorably expressed his distrust of

\footnotetext{
${ }^{1}$ Act 3, sc.1.
} 
Cassius with the words: "Yond Cassius has a lean and hungry look; / He thinks too much. Such men are dangerous. ... He reads much, / He is a great observer, and he looks quite through the deeds of men." ${ }^{2}$

Cassius, the initial driving force behind the assassination plot, realizes that the recruitment of Brutus, one of the most respected citizens of Rome, into the conspiracy will be critical in winning the people's acceptance of Caesar's death. Cassius meets with Brutus to persuade him to join the conspiracy. Knowing Brutus prides himself on his sense of honor, Cassius opens his appeal by telling him that "honor is the subject of my story." ${ }^{3}$ In fact, denigration of Caesar and flattery of Brutus are his true subjects. Cassius recounts a long-ago incident when Caesar challenged Cassius to a swim in the Tiber on a day when the waters of the river were particularly rough. Cassius accepted the challenge; eventually, Caesar was overcome and Cassius had to pull him from the river to prevent him from drowning. Another time, Cassius says, Caesar had a fever and was weak, begging for some water "like a sickly girl." These two stories, meant to show Caesar's weakness (but utterly trivial in the light of Caesar's extraordinary military career), reveal Cassius' deep bitterness over the political ascent of Caesar.

With growing eloquence, Cassius argues that Caesar's preeminent power is a threat, not merely to common citizens, but to aristocrats like Brutus: "Why man, he doth bestride the

${ }^{2}$ WiLliam SHAKESPEARE, JULIUS CAESAR Act 1, sc.2, lines 204-05, $211-$ 13. All citations to the play are from The New Folger Library Shakespeare edition, Barbara A Mowat and Paul Werstine (eds.).

${ }^{3}$ Act 1, sc.2, 1.99 
narrow world / Like a Colossus, and we petty men /Walk under his huge legs and peep about / To find ourselves dishonorable graves.” ${ }^{4}$ Men like us, Cassius seems to say, deserve recognition in life and honor upon their deaths. Cassius urges action to ensure that they do not suffer as “underlings” while all power concentrates in Caesar's hands. He proceeds to flatter Brutus by claiming that Caesar is no better than Brutus, who can boast of noble ancestors and an esteemed place in the Roman social and political order. Brutus' idealism and sense of honor may be all that he acknowledges to himself, but the insightful Cassius appeals to Brutus’ pride and vanity. He knows Brutus’ mixed motives better than Brutus himself.

Brutus is won over, and assumes leadership of the assassination plot. Cassius suggests that Mark Antony, Caesar’s loyal supporter, be slain as well, but Brutus rejects the idea, saying "Let's be sacrificers, but not butchers, Caius." ${ }^{5}$ Brutus, in one of a series of misjudgments, dismisses Antony as a mere appendage of Caesar, saying "he can do no more than Caesar's arm, । When Caesar’s head is off.” ${ }^{\prime}$ He will not allow himself to be swayed by Cassius, although Cassius wisely perceives Antony as a serious threat to the success of their endeavor.

Caesar, meanwhile, ignores various warning signs and portents, in order to uphold his public image as one who fears nothing. A soothsayer's dire warning to "beware the ides of March" goes unheeded. On that very day, Caesar is stabbed to death by the group of conspirators

\footnotetext{
${ }^{4}$ Act 1, sc.2, lines 142-45.

${ }^{5}$ Act 2, sc. 1, l.179.

${ }^{6}$ Act 2, sc.1, l. 195-196.
} 
that encircles him, pretending to be petitioning for political favors. The final stab is made by Brutus, and Caesar dies.

Word of the assassination spreads quickly, and a crowd of uneasy citizens gathers at the Capitol. Brutus assures them that “public reasons shall be rendered” to explain Caesar's death. The crowd must be large, for Brutus asks the citizens to divide themselves into two groups, one to hear a speech from Cassius, and the other to hear Brutus himself.

Just before addressing the people, Brutus encounters Mark Antony. Antony pledges his support for the conspirators, if Brutus satisfactorily explains why Caesar was killed. Brutus, sure of himself and his cause, tells Antony that he will provide good reasons, and even promises Antony that after he speaks to the crowd, Antony will be allowed to eulogize Caesar, so long as he does not criticize the conspirators. Cassius, ever politically astute and less trusting than Brutus, urges Brutus not to permit Antony to speak, but Brutus unwisely overrules him once again.

Antony, as Cassius suspected, has no intention of delivering a mere funeral oration. His true goal is to persuade the crowd that Caesar's assassination was the unjustified act of traitors. Thus the stage is set for two consecutive speeches, taking opposite sides on the momentous issue of Caesar's death. 


\section{Advocacy Lessons: Brutus’ speech}

Brutus' speech is a success at first, with the people cheering him upon its conclusion. But by the end of the scene, after Antony has spoken, the crowd is rampaging through the streets, seeking to avenge the murder of Caesar. Brutus’ speech is best understood as effective but seriously flawed. The modern-day lawyer can draw valuable advocacy lessons from both the strengths and the weaknesses of Brutus' effort. I here offer eleven such lessons.

Influencing audience membership

The key role of the audience in persuasion was identified long ago by Aristotle in his classic treatise on rhetoric. ${ }^{7}$ A speaker must persuade a particular audience at a particular time and place, in a specific context that makes the audience more or less open to the speaker’s position. Given the importance of the audience's preexisting inclinations, no advocate should pass up the opportunity to shape the composition of the audience he must persuade.

Brutus' first statement to the citizens of Rome has an important effect on the composition

of his audience. Before his formal speech, Brutus asks the people to split themselves up, some to hear him and some to hear Cassius give reasons for the slaying of Caesar. In dividing the audience between himself and Cassius, Brutus, consciously or not, initiates the persuasion process. He directs “followers of Cassius” to go with Cassius, thereby inviting the citizens of

\footnotetext{
${ }^{7}$ Lane Cooper (trans.), THE RHETORIC OF ARISTOTLE, Book 2.
} 
Rome to choose their speaker based upon their own political preferences. The citizens will align themselves based on the degree of affinity they feel for the one or the other offered speaker. Those who identify with Cassius' robust brand of realpolitik will choose him, and as a consequence, Cassius will have an audience more receptive to his arguments. Those Romans favoring a more idealistic approach to affairs of state will no doubt choose to hear Brutus, giving him an audience more inclined to accept his arguments. ${ }^{8}$

\section{Heightening speaker credibility}

As Aristotle observed, the character of the speaker (ethos) affects the audience's willingness to accept his message. Not surprisingly, an audience is more receptive to the statement of a well-respected speaker than to one held in contempt. Credibility is also enhanced by a speaker's apparent self-confidence, intelligence, belief in his cause, and sincerity. Furthermore, an advocate who voices respect for his listeners, genuinely but not obsequiously, enhances his standing with audience members.

${ }^{8}$ A remarkable example of audience shaping by a speaker occurred during the 2004 presidential campaign. Vice president Dick Cheney, speaking in New Mexico, required that all members of his audience sign a pledge to vote for the Bush-Cheney ticket; those refusing would not be allowed into the hall to hear his speech. Steve Larese, "Bush-Backers-Only Policy Riles Voters at RNC Rallies," The Boston Globe, August 9, 2004, p.A2. The tactic was too reminiscent of loyalty oaths for some voters. Id.

As a closer if hypothetical example, consider: if President Bush and former Secretary of State Colin Powell were to explain the reasons for going to war in Iraq, those with doubts about Mr. Bush's honesty might choose to hear Mr. Powell, while those who think Mr. Powell too timid in the pursuit of the war might go with Mr. Bush. Each man would have an audience somewhat more partial to his way of thinking. 
Brutus knows his strongest asset is the credibility he derives from his upright reputation in the community, and he draws upon this asset immediately. He is known as a man of honor, he reminds the Romans, and they can believe what he tells them:

Be patient till the last. Romans, countrymen, and lovers! Hear me for my cause, and be silent, that you may hear. Believe me for mine honour, and have respect to mine honour, that you may believe: censure me in your wisdom, and awake your senses, that you may the better judge. ${ }^{9}$

Brutus invites his listeners to“censure” him should they not be persuaded by what he has to say. In saying this, he acknowledges the authority of his audience and submits himself to its judgment. Brutus understands that an audience will feel well-disposed toward a speaker who not only seeks his listeners' approval but appears willing to defer to their verdict. Although people are generally flattered when their opinion is sought, a speaker suspected of false flattery will quickly lose audience respect. It is important that Brutus deliver this part of the speech with great earnestness. In one notable film version of Julius Caesar, ${ }^{10}$ actor James Mason infuses Brutus’ speech with the utmost sincerity and seriousness of purpose.

Brutus’ pride in his high station and aristocratic heritage works both for and against his credibility. The Roman audience may respect his nobility and resent it at the same time. In his

${ }^{9}$ Act 3, sc.2, 1. 13-19. Reputation will aid Brutus, but one wonders how Cassius might begin his speech; as a behind-the-scenes political manipulator, Cassius would not have shared Brutus’ sterling reputation for honesty.

${ }^{10}$ Julius Caesar (Warner Studios, 1953). The film starred Marlon Brando as Antony, James Mason as Brutus, and John Gielgud as Cassius. 
opening sentences, he must take care to eliminate any hints of condescension, disdain, or aloofness. Brutus seems a bit inclined to scold the crowd, telling the group to be silent, to stay awake and alert, and to be patient until he’s finished. His respect for the common man, one suspects, is not one hundred percent. But it's deferential and respectful enough to make the crowd feel reasonably well-disposed toward him.

\section{Framing the issue and stating a theme}

Artfully articulating the issue to be decided is critically important in advocacy. Brutus, of course, has little choice but to offer justifications for the killing of Caesar. But he can decide exactly how to frame the matter, and he does so in an advantageous way. He begins his defense of the slaying with these words:

If there be any in this assembly, any dear friend of Caesar's, to him I say, that Brutus' love to Caesar was no less than his. If then that friend demand why Brutus rose against Caesar, this is my answer: Not that I loved Caesar less, but that I loved Rome more.

As a popular leader, cheered by the people as he refused a crown proffered by Antony the day before the assassination ${ }^{11}$, Caesar undoubtedly had many supporters in the crowd now facing Brutus. Brutus’ first sentence creates common ground with these audience members and

${ }^{11}$ Casca, one of the conspirators, describes Caesar's refusal of the crown in Act 1, sc. 2 . 
establishes some rapport by identifying himself with those who admired Caesar. Brutus then articulates the question that leaps to everyone's mind-why did Brutus rise against Caesar?-in a simple, clear, straightforward manner. By unflinchingly stating the key issue before the assembly, he gives a strong impression of dealing candidly and openly with the audience. His reply to his own question is similarly plain and blunt (“this is my answer ...”). There is no equivocating, no attempt to evade or sidestep the problem, no words that hedge or obfuscate. The twelve words that follow-“Not that I loved Caesar less, but that I loved Rome more”-gives his argument a clear, simple theme, one that summarizes his case in a memorable way.

Both Brutus’ statement of the question and his thematic reply pit Brutus directly against Caesar. Significantly, throughout his speech Brutus never once mentions the participation of anyone else in the slaying of Caesar. In his telling, he alone acts ("as he was ambitious, I slew him”); the assassination is thereby portrayed as a confrontation solely between Brutus and Caesar. In putting the matter in this way, he foregoes the advantage of showing that others shared his view of the threat posed by Caesar. But framing the issue in this way promotes Brutus’ argument in several important ways. First, by assuming full personal responsibility for the slaying, Brutus displays boldness, self-confidence, and political courage. His boldness implies there is nothing shameful about the deed, nothing a proud, patriotic man would shrink from defending. Second, he makes his defense of the assassination an entirely personal one, rendering his individual reputation for honor and love of country all the more significant. Third, he avoids the image of a large group of men ganging up on one unarmed, unsuspecting individual. Finally, he places himself on an equal footing with Caesar, contrasting his vision of 
Rome with Caesar's. Implicitly, Brutus offers himself to the crowd, in need of a leader to follow Caesar, as a political leader equivalent to, if not better than, the once great Caesar.

\section{Supporting Evidence}

The advocate must provide convincing support for the argument that is encapsulated in the thematic statement. For Brutus, this means showing why his love for Rome required him to slay Caesar, using the basic tools of advocacy: reasons, logic, facts, examples, probabilities, inferences, physical proof, documentary evidence, witness testimony.

Brutus' defense of the slaying proceeds:

Had you rather Caesar were living, and die all slaves, than that Caesar were dead, and live all free men? As Caesar loved me, I weep for him; as he was fortunate, I rejoice at it; as he was valiant, I honor him; but, as he was ambitious, I slew him. There is tears for his love; joy for his fortune; honor for his valor; and death for his ambition. Who is here so base that would be a bondman? If any, speak, for him have I offended. Who is here so rude that would not be a Roman? If any, speak, for him have I offended. Who is here so vile that will not love his country? If any, speak, for him have I offended. I pause for a reply.

Citizens: None, Brutus, none.

Brutus: Then none have I offended. .... ${ }^{12}$

${ }^{12}$ Act 3, sc.2, 1. 19-38. 
Brutus proceeds by posing another question: "Had you rather Caesar were living, and die all slaves, than that Caesar were dead, to live all free men?” The dichotomy he creates, between freedom and slavery, leaves no real choice-any sane Roman will choose freedom over slavery. Brutus asserts that Caesar was “ambitious,” for which he suffered death. He reiterates the point by launching into a series of rhetorical questions that characterize anyone offended by the slaying of Caesar as base, vile, and unpatriotic. Each question is cleverly crafted so as to incorporate the premise Brutus wants the crowd to accept-that Caesar's ambition was to become dictator and enslave Rome’s citizens-as if that premise had been proved.

But it is not proved. The speech fails to present any evidence to support its basic charge against Caesar. Brutus tells the people his conclusion about Caesar’s desire to enslave them, but he leaves out all the reasons, facts and examples that support that conclusion. In essence, he says: I know Caesar was ambitious, and I acted on this knowledge-and that's all you people need to know. He relies for his persuasive power on his prior reputation, his rhetorical art, his confidence in his cause, and his sincerity.

A speaker's sincerity, self-confidence, and strong belief in the rightness of his own cause can have a powerful effect on the audience. Brutus is nothing if not confident in himself, in his position, and in his own rectitude. In this respect, his pride and sense of inbred superiority serve him well. But perhaps these same qualities lead him to feel no call to explain to the common folk his reasoning process. Whatever the reason, he has neglected the evidentiary requirements of persuasive argument. Nevertheless, the crowd accepts his defense; for the time being, Brutus’ 
heavy reliance on his honor, reputation, sincerity, and confidence in his cause serves to win over the crowd.

\section{Meeting the audience's emotional needs}

The crowd is not thoughtful about the problem before it, or it would not so readily accept Brutus' assertions without any real proof. But it would be wrong to attribute Brutus’ success simply to the crowd's lack of intelligence or political sophistication. Brutus succeeds because he provides what his audience needed most in the frightening circumstances surrounding political assassination: strong, confident leadership. Facing the threats of anarchy or civil war with their former leader, Caesar, dead, the people are anxious, alarmed, and afraid. In this agitated emotional state, they need reassurance that someone trustworthy can take control of the situation. Thus they cheer Brutus’ speech while missing his point about avoiding one-man government; their strong desire for a new leader is expressed in the citizens' appreciative cries, "Let him be Caesar,” and “Caesar's better parts / shall be crown'd in Brutus."”13

Brutus communicates strength of purpose and an unshakeable conviction in the rightness of his action. It is this strength, perhaps more than anything specific that he says, that reassures the people and allays their fears and anxieties. To show the crowd the intensity of his sense of patriotism and honor, he promises to sacrifice his own life "should it please my country to need

\footnotetext{
${ }^{13}$ Act 3, sc.2, 1. 53-55.
} 
my death.”14 The crowd, needing his leadership, shouts "Live Brutus, live, live!”15 and offers to build him a statue with his ancestors. The people need the security and comfort of a new leader who can fill the vacuum left by Caesar's death, more then they need a well-reasoned answer to the quesion Brutus first posed about why he attacked Caesar.

With the crowd actively on his side, Brutus takes his leave at an emotional peak. But he makes the mistake of urging the citizens to stay to hear Antony give a funeral address.

\section{Rhetorical style}

Despite the lack of evidence, Brutus wins the crowd over, and his rhetorical technique contributes to this success. The speech is artfully crafted, with strong parallel statements and rhythmic repetitions. Many of his sentences are composed of short phrases of five words or less, easily digested by listeners. A surprising number of sentences are composed almost entirely of words of one syllable. ${ }^{16}$ This renders key passages unusually blunt and easily grasped, e.g., “... this is my answer. Not that I loved Caesar less, but that I loved Rome more.”

The rhetorical questions are similarly heavily monosyllabic: "Who is here so base that would be a bondman? If any, speak, for him have I offended. Who is here so rude that would not

${ }^{14}$ Act 3,sc.2, 1. 49.

${ }^{15}$ Act 3, sc.2, 1. 50.

${ }^{16}$ One eminent critic observed: “No play of Shakespeare’s has so many [monosyllables], so superbly used.” Mark van Doren, SHAKESPEARE 182 (1939). 
be a Roman? If any, speak, for him have I offended. Who is here so vile that will not love his country? If any, speak, for him have I offended.” The rhetorical value of questions is clear to Brutus; once he gets the crowd's attention, he asks no fewer than five of them (the three serial questions; the earlier rhetorical question about dying all slaves; and the issue-defining question of why Brutus rose against Caesar). Just before he leaves, he asks another, when he says Antony shall have a place in the new political order, and adds, "as which of you shall not?” Questions have several virtues. They focus the mind in a way that other sentences often do not; they engage the audience with the questioner in an active, participatory way by calling for the listener to provide an answer. The listener who doesn't know the answer to a genuine inquiry is temporarily made to feel awkward or uninformed, and is in the debt of the speaker who then provides an answer.

Questions, of course, are a staple in teaching, and advocacy is in significant part a teaching effort. Even if the audience members know the facts beforehand, the advocate teaches them how to fit the facts together, and explains their significance for the issue in dispute. Because the advocate is not merely a teacher, but a persuader, his questions may be "loaded." The advocate's conclusion is already drawn, and his questions serve as signposts along the way to those conclusions.

Brutus' reliance on the dichotomy also serves his persuasion goals. His sharply drawn dichotomies-freedom versus slavery; Caesar living versus Caesar dead; loyalty to a friend versus loyalty to Rome-portray the situation facing himself and Rome as stark, take-one-or-the-other 
sets of choices. As with any rhetorical tool, the dichotomy can mislead the audience. When there are in reality more than two alternatives, the either/or choice presented by the advocate does not suffice to describe the available options. Earlier in the play, Brutus himself had recognized that his prediction about Caesar's dictatorial designs was somewhat doubtful; yet his rhetoric on the point is strong and admits of no doubt.

\section{Minimizing adverse facts}

One of the most important decisions an advocate must make is how to deal with adverse facts. Brutus’ explanation of the concerted, bloody attack on Caesar shows a determination to deal cautiously with facts that can have a strong negative effect. His first promise to the crowd, that "public reasons will be rendered of Caesar’s death,” carefully avoids any reference to how that death occurred. His first mention of the slaying states that Brutus "rose against" Caesar, a well-chosen phrase more readily associated with political uprising than with a criminal act. The death is spoken of only in general terms; details, as Antony later shows, can only appall the crowd. The only detail given by Brutus is a reference to the dagger he used against Caesar. The dagger is mentioned briefly at the end of the speech, not in the context of a description of the attack, but in a noble offer by Brutus to kill himself with the same dagger if his country needs his death.

The difference between Brutus’ and Antony’s account of Caesar’s death could not be more dramatic. Like a prosecutor of a particularly heinous crime, Antony dwells upon the details 
of the killing. Antony emphasizes each stab wound that pierced Caesar's mantle; he names various conspirators; and he uses the bloody, mutilated body of Caesar as his principal prop to demonstrate the horrific nature of the attack. ${ }^{17}$ His listeners can have no doubt that Caesar was stabbed again and again by the sharp daggers of a group of men bent upon murder.

\section{Assessing audience understanding}

An advocate needs to know if his message is getting through to his audience. Brutus appears not to have accurately gauged his audience's understanding of his message. The citizens' responses (“Let him be Caesar” and “Caesar's better parts / Shall be crown'd in Brutus.” ) show they have not grasped his reason for eliminating Caesar. Brutus has not explained his political point about Caesar's threat to republican government clearly enough for these Romans, who, after hearing him, are looking for a replacement Caesar.

For an agitated audience like this, Brutus himself must be more patient, first providing the necessary reassurance of safety and security, and then taking the time to carefully explain his idea for the political order following the sudden death of Caesar. By disregarding the crowd's reaction, Brutus missed a crucial opportunity to win the people's commitment to republican government. When Antony, a strong leader with no such commitment, later speaks to the people, he does not have to face a crowd that is skeptical of one-man rule.

${ }^{17}$ Act 3, sc.2, 1. 186-209. 
The contrast with Antony's speech is again instructive. Antony pauses to let the crowd react to his words; he interacts with them; he asks them questions. His alertness to their feelings is palpable, as he repeatedly incites the people to emotional outbursts, calms them, and then stirs them up again. He can see and hear his audience’s responses to his words.

If an audience is passive, like a jury, an advocate still must make the effort to assess its understanding of the message. Observing body language can give clues to audience attentiveness, doubt, confusion, and agreement. A full range of emotional reactions, such as anger, sympathy, dismay, surprise, disdain, disgust, and disbelief, are often revealed in facial expressions. And even the quiet audience may occasionally laugh, grunt, snicker, or show some other vocal sign of its thinking about an advocate, his client, or his case.

\section{Achieving proper proportion}

In another crucial way, Brutus’ advocacy fails. His effort at persuasion is temporarily successful, but it lacks the substance, depth and detail that his momentous subject-the assassination of Rome's most prominent and heroic political figure-requires. His argument lacks proportion: to justify such a weighty deed, he offers a skimpy speech. In delivering this speech in one film version of the play, actor James Mason, as Brutus, spends only three minutes addressing the crowd, before taking his leave. The citizens are appeased, but not educated to truly understand the nature and consequences of Caesar's ambitions. 
Shakespeare here demonstrates that there are degrees of persuasion. Persuasion can be superficial and temporary, rather than deeply convincing. What more might Brutus have said to have been more effective? Asserting Caesar was ambitious can temporarily satisfy an audience if the advocate's credibility with the audience is high, but it is not enough for a lasting persuasive effect. Supporting evidence, e.g., examples of Caesar's thirst for power in politics or in the army, would form the basis for a more enduringly persuasive argument. Perhaps Caesar’s ambition for power was discoverable in his own words, either in private communications or in public remarks. Would-be dictators sometimes propound a philosophy that justifies dictatorship and rationalizes cruelty. Caesar had a public record. Did his deeds betray a ruthlessness in the exercise of his power as a general or as a public official? Were Caesar's ambitions revealed by his imperious behavior, his disdain for law, his pushing aside others in his grasping for more power? Instances in which Caesar demanded servility, spent public money on statues of himself, refused to listen to pleas for justice, exercised his power mercilessly, or put his own interests above those of his country, would go far toward persuading the people that Caesar posed a grave threat to the Roman way of life. Such specific evidence of wrongdoing would let the people draw their own conclusions about Caesar, rather than leaving them to rely entirely on Brutus’ unsupported conclusion.

Antony’s speech, by contrast, is well proportioned. There are twenty-two lines devoted to refuting Caesar’s alleged ambition; twenty-four lines discussing and describing his murder; and twenty-nine lines devoted to Antony’s chief piece of evidence, Caesar's will. This allocation gives appropriate space to each of his principal points, while endowing the speech with a well balanced shape and structure. 


\section{Treating adversaries with civility}

When launching an argument, it is tempting to attack an one’s adversary as well as his opposing argument. Treating an opponent with disdain may be emotionally satisfying, but there are clear dangers for the overly aggressive advocate. Being gracious to an adversary can redound to the benefit of the advocate, generating audience respect for courtesy and decency. Treating an adversary shabbily may lead to audience alienation from the advocate, and generate sympathy for the mistreated party.

Brutus treats Antony with great courtesy and civility. Indeed, failing to grasp Antony’s guile, he goes so far in this direction as to be overindulgent, conceding to Antony advantages that should have been withheld from him. Having control of the public forum, Brutus did not need to allow Antony a chance to speak at all. Cassius warned against this in no uncertain terms, telling Brutus, "You know not what you do. Do not consent /That Antony speak in his funeral. / Know you how much the people may be moved / By that which he will utter?" 18 Brutus too readily assumes Antony’s good faith, accepting Antony’s private promise that he will not speak against Brutus. Brutus departs alone from the forum immediately following his own speech, publicly demonstrating his faith in Antony.

Brutus treats his late adversary, Caesar, with respect as well. He says that Caesar was “valiant,” and deserved honor for his valor, a concession that works in Brutus’ favor, bolstering the impression that Brutus is being entirely forthright about Caesar, acknowledging his strengths

\footnotetext{
${ }^{18}$ Act 3, sc.1, l. 255-259.
} 
as well as his faults. ${ }^{19} \mathrm{He}$ is even generous to Caesar, entreating the citizens to listen to Antony speak of “Caesar’s glories.”

\section{Personality of advocate}

Personal qualities of an advocate can support or interfere with successful advocacy. Perhaps the most difficult part of advocacy to master is self-knowledge: to know your own shortcomings and compensate for them.

Shakespeare shows Brutus making serious mistakes in judgment, particularly with respect to Antony. Despite having good reason to distrust Antony and excellent advice from Cassius, Brutus gives Antony permission to speak, taking Antony's word that he will not criticize the murder. Brutus then compounds the error by leaving right after his own speech, giving Antony free rein to speak to the crowd without restraint. Antony's powers of persuasion, as revealed in his speech, far eclipse those of Brutus, and he uses his skills to the utmost to contradict and undermine Brutus. Failing to discern the true intent of Antony, the susceptibility of the citizenry, and the shortcomings of his own speech, Brutus leaves the scene fully satisfied with himself. Perhaps, hearing Antony's first words promising to bury Caesar, not to praise him, he walks off feeling reassured.

In a matter so critical as the advocacy of assassination, Brutus ought to leave as little as possible to chance, and keep maximum control of the situation. Yet there is something in his

${ }^{19}$ Brutus would only damage his own credibility if he tried to deny what all Romans knew to be true about Caesar. 
personal make-up, be it arrogance, an irrational belief in the power of his own righteousness, a failure to understand and empathize with others, or other character flaw, that leads him to make these mistakes, and undermine his own cause in the process.

Consider another mistake that Brutus makes, that of failing to pick up on the audience's misapprehension of his message. When some citizens suggest that he be the next Caesar, why does Brutus ignore their faulty interpretation? Perhaps, in some way, he aspires to be like Caesar. Within the conspiracy he imperiously assumes the lead, taking over from Cassius, and proceeds to make crucial decisions by himself. Rather than heed the politically discerning Cassius, he puts his faith in himself as the sole source and guarantor of wisdom. He is won over to the conspiracy in part by Cassius' flattery to the effect that he, Brutus, is as good as Caesar. Though this is patently false (certainly in terms of worldly accomplishment), Brutus accepts it as true. Vanity, self-regard, and pride undercut Brutus’ advocacy, as much as Antony’s powerful opposing remarks.

\section{Advocacy Lessons: Antony's speech}

Marc Antony’s speech is a model of rhetorical art, the brilliant use of language to guide an audience to the conclusions the speaker wishes it to draw. He uses well chosen facts, engages with the audience, assesses the people's reactions as his argument proceeds, stimulates their emotions, and appeals effectively to patriotism, friendship, and human self-interest, doing all this with thrilling rhetorical flair.

Unfortunately, the speech is also a model of deceit and manipulation. Shakespeare 
illustrates the unpleasant truth that an advocate need not be truthful to be effective. Antony repeatedly misleads his audience as to his true thoughts and intentions. He claims he respects the conspirators, but in fact he despises them. He says he won't praise Caesar, and then he exalts him. He denies he is a skilled orator, in the midst of a dazzling oration. He says he won't read Caesar's will, but later reminds the crowd that they wanted him to read it, which he does. He says he doesn't intend to stir the crowd to mutiny and rage, and he does exactly that. Antony has no compunction about his dissembling. To gain the chance to sway the crowd, he falsely promised Brutus that he would not criticize the conspirators. He lies, effectively and convincingly, to almost all of the characters in the play. ${ }^{20}$

\section{Distraction}

Antony first appears before the crowd while Brutus is speaking, with the body of Caesar, still clothed in his blood-soaked tunic. At this point, the crowd seems favorably disposed towards Brutus. What better way to distract an audience's attention from one's opponent in mid-speech? There are no stage directions, so we can only wonder how Brutus physically reacts. Does he flinch? Take an involuntary step back from the body of the man he has just killed? Stare with pupils dilated at the awful sight? Whatever his physical reflex, Brutus cannot ignore the interruption, and he responds with these words:

${ }^{20}$ Brutus, the man of honor who uses political assassination to achieve his goals, can hardly complain. 
Here comes his body, mourned by Mark Antony, who, though he had no hand in his death, shall receive the benefit of his dying, a place in the commonwealth, as which of you shall not? With this I depart, that as I slew my best lover for the good of Rome, I have the same dagger for myself, when it shall please my country to need my death. ${ }^{21}$

Antony does not breach his promise by so appearing, since Brutus had given him permission to "speak in Caesar's funeral.” But the distraction should be another warning to Brutus that Antony is not to be trusted. Brutus, however, promptly brings his own speech to an end (perhaps cutting his speech short), and makes his own situation worse by walking away from the crowd, leaving himself no chance to monitor or rebut what Antony says.

\section{Addressing pre-existing audience opinions and knowledge}

No audience is a blank slate; people come to a presentation with a set of ideas, opinions, and values that may directly affect their receptiveness to the advocate's message. At the outset of his remarks, Antony faces a serious problem that sometimes occurs in advocacy: his audience comes to him with markedly hostile opinions and ideas. The audience of Roman citizens has sided with Brutus after his speech. They now hold negative opinions about Caesar: "This Caesar was a tyrant”; “Nay, that's sure. We are blest that Rome is rid of him.”22 The crowd also possesses knowledge that Antony was a loyal follower of Caesar; indeed, many witnessed the

\footnotetext{
${ }^{21}$ Act 3 , sc. 2, 1. 43-49.

${ }^{22}$ Act 3, sc.2, 1. 76-78.
} 
scene on the Lupercal, described earlier in the play, ${ }^{23}$ in which Antony publicly offered a crown to Caesar.

One member of the crowd articulates the audience's attitude, by warning that Antony had better not say anything bad about Brutus. Antony addresses their concern about his attitude and intentions right away.

Friends, Romans, countrymen, lend me your ears;

I come to bury Caesar, not to praise him.

The evil that men do lives after them,

The good is oft interred with their bones;

So let it be with Caesar. The noble Brutus

Hath told you Caesar was ambitious;

If it were so, it was a grievous fault,

And grievously hath Caesar answer'd it.

Here, under leave of Brutus and the rest,--

For Brutus is an honorable man;

So are they all, all honorable men.--

Come I to speak in Caesar's funeral. ${ }^{24}$

Like Brutus before him, Antony promptly and directly addresses the audience’s immediate concern. Antony's initial praise is not for Caesar, but for the conspirators. Antony

${ }^{23}$ Act 1, sc.2, 1. 245-261.

${ }^{24}$ Act 3, sc. 2, 1. 82-93. 
gives the slightest hint of disagreement with Brutus in the phrase "If it [Caesar's ambition] were so, it was a grievous fault," ${ }^{25}$ but the hint is subtle and offered in the midst of Antony's clear disclaimer of any defense of Caesar. Antony reassures the citizens that his thinking is like theirs, asserting his belief that Brutus is noble and honorable. He is lying, but if he delivers these lines with the appearance of sincerity and conviction, his credibility with the audience will be enhanced.

Antony understands the crowd's high opinion of Brutus as a man of honor, and knows Brutus has staked his entire argument on their belief. Antony repeatedly proclaims not only Brutus, but all the conspirators to be honorable men, linking them together in a refrain that becomes more and more insupportable as the speech proceeds. He knows he has succeeded in dislodging this pre-existing crowd opinion when the citizens themselves scorn the refrain ("They were traitors! Honorable men!”26).

Ironically, it is not just Antony who must deal with an audience that starts out with views opposite to his own. When Brutus addressed the crowd, the people held Caesar in high regard, and Brutus, like Antony, begins his speech with a statement that identifies himself with the crowd's opinion, and not his own contrary one. While Antony begins by saying he won't praise Caesar, Brutus begins by saying he loved Caesar. Each man must then find a smooth transition to his principal point, Brutus that Caesar deserved death and Antony that Caesar deserved praise.

\section{Creating a Theme}

${ }^{25}$ Act 3, sc.2, 1.88 (emphasis added).

${ }^{26}$ Act 3, sc.2, 1. 165. 
An advocate imparts his message most effectively if he can adopt an easily understood theme that will resonate with the audience. Antony initially faces a dilemma. He cannot state his theme openly, because he is hiding his true purpose, to persuade the crowd that Caesar was not ambitious and that Brutus was a traitor. In an inspired ironic maneuver, he temporarily adopts the theme of his adversary, proclaiming the virtue of Brutus and the other "honorable men” who joined in killing Caesar.

A theme more subtly woven throughout the speech focuses on the value of friendship. Antony cites four crucial instances of friendship: his own friendship with the crowd; his personal friendship with Caesar; Caesar’s friendship with Brutus; and Caesar’s friendship with the citizens of Rome. He employs each friendship to undermine what Brutus said, with increasing power and effectiveness.

First there is the friendship Antony offers to his audience. His initial word to address them is "Friends," and he later calls them "gentle friends," and "good friends, sweet friends.” He takes various opportunities to compliment them (for example, calling them "kind souls”). He labels their tears for Caesar "gracious drops.” He openly shares his feelings with them, at one point weeping before them (though very likely the tears are bogus).

Antony’s first positive words about Caesar recall him as a loyal friend ("he was my friend, faithful and just to me”). This is the first piece of evidence offered to show the crowd that Caesar was a good man. Antony highlights the emotional value of friendship by stopping in mid- 
speech to say "Bear with me / My heart is in the coffin there with Caesar, / And I must pause, till it come back to me." ${ }^{27}$ Antony later refers to himself as "a plain blunt man that love my friend" to show his own simple, good character. ${ }^{28}$

The third friendship Antony exploits to great effect is that between Brutus and Caesar. Antony memorably describes Brutus as “Caesar’s angel,” claiming Caesar loved him above all others. ${ }^{29}$ Realizing that Brutus is one of the killers, Caesar dies, but not of dagger wounds. Rather, in Antony's account, what kills Caesar is Brutus' betrayal of this supposedly sublime friendship: "For when the noble Caesar saw him stab, / Ingratitude, more strong than traitors' arms / Quite vanquished him.” Seeing Brutus desert him "burst his mighty heart” and "great Caesar fell.. ${ }^{30}$ Having persuaded the crowd that Caesar represented all of the people, Antony artfully turns Brutus' betrayal of a friend into treason against his countrymen (“Then I, and you, and all of us fell down / Whilst bloody treason flourish'd over us.”).

The last friendship, in which Antony portrays Caesar as a great and generous friend of the people, is used by Antony to rouse the crowd into a frenzy. "When the poor have cried,

${ }^{27}$ Act 3, sc.2, l.115-117.

${ }^{28}$ Act 3, sc.2, 1. 230-31; note the prominent use of monosyllables, supporting his claim to be plain and blunt.

${ }^{29}$ Evidence in the play suggests this is not true. When Caesar first sees Brutus on the morning of the assassination, he only asks Brutus for the time. When Brutus answers, he is coldly thanked. Act 2, sc.2, 1. 120-122. There is no warmth between the two men. In truth, the only person Caesar talks to intimately is Antony.

${ }^{30}$ Act 3, sc.2, 1.196-201. 
Caesar hath wept,” Antony says early on. He tells the crowd that Caesar loved them, and produces written evidence of that love, Caesar's will. When Antony finally reveals Caesar's bequests to the people of Rome, including a gift of seventy-five drachmas to each and every Roman citizen, the calls for revenge are everywhere, and the crowd rushes off to hunt down Caesar's killers.

Thus friendship, with its associated qualities of affection, loyalty, generosity, and occasionally, betrayal, provides Antony with an affecting theme and an emotionally compelling set of focal points for his argument.

\section{Substantiating the argument: Selecting facts}

In formulating an argument, an advocate must carefully choose from the infinite number of facts that surround any significant event. Antony cites a few instances in Caesar's life that challenge the charge of ambition that Brutus has leveled against Caesar:

He was my friend, faithful and just to me:

But Brutus says he was ambitious;

And Brutus is an honorable man.

He hath brought many captives home to Rome,

Whose ransoms did the general coffers fill:

Did this in Caesar seem ambitious?

When that the poor have cried, Caesar hath wept; 
Ambition should be made of sterner stuff:

Yet Brutus says he was ambitious;

An Brutus is an honorable man.

You all did see that on the Lupercal

I thrice presented him a kingly crown,

Which he did thrice refuse: was this ambition?

Yet Brutus says he was ambitious;

And, sure, he is an honorable man. ${ }^{31}$

Antony culls a handful of facts from Caesar's career and character, selected from Caesar's rich, eventful life. The ones chosen here, plus the evidence of Caesar's will Antony introduces later in the speech, show how Caesar improved the citizens' lives while he was living, and even benefits them after his death. Some of these facts audience members will recall of their own knowledge (e.g., the captives brought to Rome, the public offers of the crown), insuring their belief in those facts and making Antony seem candid and credible.

These examples work for Antony even though they are hardly conclusive evidence of Caesar's lack of ambition. His first example, that of Caesar's faithful friendship, is potent not for its relevance (a friend of Antony’s may still covet unrestrained political power) but for its humanizing of Caesar. Every advocate for an individual advances his cause by making his client more likable and admirable. People value friendship; a faithful friend is unselfish, reliable, loyal, and trustworthy. When an audience values an individual's positive qualities, it will be skeptical

${ }^{31}$ Act 3, sc.2, 1. 94-108. 
of the apparently contradictory claim that he is a fundamentally bad man. ${ }^{32}$

The second example recalls Caesar as war hero, winning battles and bringing riches home to Rome (again, not inconsistent with political ambition). In the third example, the sensitive Caesar weeps with the poor, but a politician's tears, like a crocodile's, are hardly to be trusted. Finally, Antony recalls an incident recently witnessed by the people themselves, in which Caesar refuses a crown offered by Antony in front of a crowd of Romans, over and over and over again. Again the evidence is inconclusive; Caesar seems to protest too much that he doesn't want a crown, and the whole scene seems as likely as not to have been a bit of political theater staged by Antony to allay the very suspicions shared by Brutus and others that Caesar did indeed desire imperial powers. One eyewitness, the conspirator Casca, reported that Caesar spurned the crown most reluctantly ("he was very loath to lay his fingers off it.”). ${ }^{33}$ Upon seeing the crowd's favorable reaction to his refusal, Caesar added more drama, by baring his neck and “offering them his throat to cut." ${ }^{34}$ Even though Casca was not a witness friendly to Caesar, his account has the ring of truth. ${ }^{35}$

Why is the crowd persuaded by these examples to question Brutus' claim that Caesar was ambitious, despite the logical flaws in Antony’s reasoning? Antony’s carefully selected facts

${ }^{32}$ For a theoretical explanation of this phenomenon, see Dan Simon, A third view of the black box: cognitive coherence in legal decisionmaking, $71 \mathrm{U}$. Chi. L. Rev. 511(2004).

${ }^{33}$ Act 1, sc.2, 1.252.

${ }^{34}$ Id. at l. 276.

${ }^{35}$ We know, for example, that Caesar went to the Capitol on the day of the assassination in part because he was expecting the senators to offer him a crown. Act 2, sc.2, 1. 98-99. 
have built up Caesar's credibility, by making him seem a faithful, empathetic, generous, heroic, and public spirited leader. In selecting these particulars, Antony as advocate implicitly argues that these few facts accurately represent the whole man. Antony has highlighted memories of the man the crowd holds dear, and interpreted those memories most favorably to Caesar. Antony's interpretation is given through his brief commentary on the facts, which tend toward questions (“Was this ambition?”; “Did this in Caesar seem ambitious?”) rather than his own definitive answers. By refraining from imposing interpretations on the crowd, Antony lets the crowd feel it is thinking through the matter on its own and coming to its own conclusions. Of course, his questions clearly guide the audience members to consider the matter of Caesar's ambition as Antony does, and Antony makes rational consideration more difficult by immediately creating an emotional moment—claiming to be overcome by mourning for his friend, he weeps over Caesar as he pauses to let his argument sink in.

\section{Monitoring audience reaction}

Like any good advocate, Antony needs to know if his appeal to the crowd is working. He follows his praise of Caesar with a question for the citizens:

I speak not to disprove what Brutus spoke,

But here I am to speak what I do know.

You all did love him once, not without cause:

What cause withholds you then to mourn for him? 
O judgment! Thou art fled to brutish beasts,

And men have lost their reason. Bear with me:

My heart is in the coffin there with Caesar, and I must pause till it come back to me. ${ }^{36}$

The question invites the citizens to rethink their negative attitude toward Caesar and to recall their past love. The pause allows the citizens to discuss what they've heard, and actively engage with Antony's ideas. Their comments indicate they are being persuaded, as one citizen declares "there is much reason in his sayings," and another says "Caesar has had great wrong.” A third onlooker thinks aloud: "He would not take the crown; / Therefore 'tis certain he was not ambitious.” Antony is well attuned to his audience throughout the entire speech, and doubtless he deliberately paused at this point to eavesdrop on the people's reactions. If this seems too manipulative, recall that Antony has already deceived the audience with his claim that he will not praise Caesar and he now disingenuously adds that he is not trying to disprove Brutus’ words.

Throughout his oration Antony engages with the audience and gives himself an opportunity to learn their state of mind. Some interactions are physical. He asks their cooperation in forming a circle around Caesar's body, which they willingly do. When he changes his location, he asks them for leave to descend, and gets their positive reaction. The physical interplay gives Antony feedback from their body language; he will be able to tell if their cooperation is grudging and resentful, or readily and freely granted.

More significantly, Antony and the audience verbally interact a dozen times, allowing

${ }^{36}$ Act 3, sc.2, 1. 109-117. 
Antony regularly to assure himself that the audience is following his argument and turning to his point of view. Several interactions center on Caesar's will. Antony feigns a reluctance to read it to the people, while hinting at its contents, and they insist that he read it. Before he reads the will, he elicits an expression of support from the crowd that clearly signals he has won them over:

Antony: I fear I wrong the honorable men Whose daggers have stabb'd Caesar; I do fear it. $4^{\text {th }}$ Cit: They were traitors: honorable men!

Citizens: The will! the testament!

Sec. Cit: They were villians, murderers. The will! Read the will. ${ }^{37}$

Once he is assured of the citizens' rejection of Brutus and his accomplices, Antony can move forward with his plan to inspire the crowd to violence.

\section{Emotional Appeals}

Antony infuses his speech with strong emotional appeals. During the pause he takes to recover from his grief, one onlooker observes: "Poor soul! his eyes are red as fire with weeping."38 Antony's tears (feigned or not) inspire sympathy and even admiration; a member of

${ }^{37}$ Act 3, sc.2, 1. 163-168

${ }^{38}$ Act 3, sc. 2, l. 127. 
the crowd is moved to say, “There’s not a nobler man in Rome than Antony.”39

Antony uses his own emotions several times during the speech as a way to show the crowd how it should feel. He thus leads the crowd in its emotional responses: he weeps over Caesar's body, and later they weep; he is angry, and later they are angry; he mourns the loss of Caesar, and they follow him in mourning. At one point, when he gathers the people around Caesar's body, he even cues the audience’s emotions, saying, "If you have tears, prepare to shed them now." ${ }^{40}$ At another point, he prepares them for hearing Caesar's will by saying "it will inflame you, it will make you mad." 41

Like a conjurer, Antony is able to call up powerful emotions at will, stirring his audience to sorrow, pity, affection, shock, horror, and rage. He takes them to one emotional peak after another as he shows Caesar’s ripped mantle, exhibits his bloody corpse, and reads his will. In focusing on the mantle Caesar wears, Antony points out the places where Cassius stabbed, and Casca stabbed, and Brutus stabbed. (No matter that he could not possibly have known which rents in the material were made by which daggers; Antony values a dramatically told story more than he values accuracy).

Antony ends his account of the murder with the most dramatic visual evidence of all, the

\footnotetext{
${ }^{39}$ Act 3, sc.2, 1. 128.

${ }^{40}$ Act 3, sc.2, 1. 181.

${ }^{41}$ Act 3, sc.2, 1. 156.
} 
bloodied body of Caesar. The shocked citizens cry out ("O piteous spectacle!” "O noble Caesar!” "O woeful day!” “O traitors! villians!” “O most bloody sight!” "We will be revenged”22). They are ready to avenge the murder and kill the conspirators, but Antony has more emotionally charged things to say to them.

Twice he excites the crowd to wreak havoc, and then calms them, only to rouse them yet again to the utmost level of rage as he reads Caesar's will. After Antony tells the crowd of Caesar's bequest of money to each and every Roman, evidence of Caesar's love for the common citizen, he cries out “Here was a Caesar! When comes such another?”43 The reply comes, "Never, never!" and the crowd, in a frenzy of grief and rage, goes off to riot. In the effort to hunt down the killers of Caesar, the raging mob meets with a poet in the street who shares the same last name as one of the conspirators, and savagely attacks him. ${ }^{44}$

Emotional appeals are not simply to be condemned as manipulative, though Antony's speech is certainly that. His appeals are often false, and serve his vengeful and violent ends. But emotion can serve legitimate purposes as well, in honest advocacy. All advocates must show they care about their causes, and that those who sit in judgment also have reason to care. Seeking justice, like seeking revenge, can legitimately stir deep feelings. ${ }^{45}$ However false Antony is about

${ }^{42}$ Act 3, sc. 2, 1. 210-215.

${ }^{43}$ Act 3, sc.2, 1.266.

${ }^{44}$ Act 3, sc. 3.

${ }^{45}$ It is no accident that some of the most effective advocacy in the twentieth century came out of the civil rights movement, with powerful appeals to 
his true purposes in addressing the crowd, his strong belief in his cause is communicated powerfully and effectively.

\section{The power of suggestion; allowing the audience come to its own conclusion}

Antony never forces his conclusions upon his audience. He is a master at introducing his ideas without demanding that the audience adopt them. Early in his speech, for example, Antony is careful not to appear to directly challenge the crowd's rejection of Caesar. Questions, rather than accusations, suggest to the citizens that they reconsider their ill-disposition toward Caesar (e.g., "Did this in Caesar seem ambitious?”; "What cause withholds you now to mourn for him?”). Even his rebuke of men who "have lost their reason" is addressed to the abstract figure of "judgment" rather than to the people directly. And his use of the word "brutish," so close in sound to the name "Brutus," constitutes an almost subliminal suggestion about how to think about Brutus.

Though he desires the crowd to rise up against Brutus and his cohorts, Antony says:

But yesterday the word of Caesar might

Have stood against the world; now lies he there,

And none so poor to do him reverence.

O masters! If I were dispos'd to stir

both the intellect and the heart. For a prime example of a stirring and rational argument, see Martin Luther King, Jr. Letter from Birmingham Jail. 
Your hearts and minds to mutiny and rage,

I should do Brutus wrong, and Cassius wrong,

Who, you all know, are honorable men.

I will not do them wrong; I rather choose

To wrong the dead, to wrong myself, and you

Than I will wrong such honorable men. ${ }^{46}$

In this brief passage, Antony introduces three of his key ideas without directly asking the crowd to adopt them. He suggests mutiny by saying the word, though not advocating it (even seeming to disavow it). He suggests the emotional state-rage-that befits the moment, but again does not endorse it. And he emphasizes the wrong that has been done by repeating the word six times, without demanding that the crowd accept the proposition that Caesar has been wronged. In the midst of these repetitions of "wrong," he first mentions the name of Cassius. He will not tell the citizens what to do, but will instead put ideas in the air, show his listeners what the facts (carefully selected) are, obliquely suggest the appropriate emotional response, and let them reach their own (i.e., his) conclusions.

The audience, expertly led, is the first to call Brutus and the rest "traitors"; only after this happens does Antony himself call their actions "treason.” Similarly, the audience is the first to openly discard the “ honorable men” label; Antony pretends to still believe in this characterization until the crowd itself has decisively rejected it.

${ }^{46}$ Act 3, sc.2, 1. 130-139. 
How he induces the crowd to draw the conclusion that the conspirators were dishonorable traitors is both marvelous and cunningly manipulative. He informs the crowd of his final piece of evidence, the will of Caesar.

But here's a parchment with the seal of Caesar;

I found it in his closet, 'tis his will.

Let but the commons hear this testament-

Which, pardon me, I do not mean to read-

And they would go and kiss dead Caesar's wounds,

And dip their napkins in his sacred blood,

Yea, beg a hair of him for memory,

And, dying, mention it within their wills,

Bequeathing it as a rich legacy

Unto their issue. ${ }^{47}$

The citizens, seeing the will in Antony's possession and told its contents are extraordinary, cry out “The will, the will! We will hear Caesar’s will.” Antony, claiming he does not intend to read it, gives another provocative taste of its contents, saying

Have patience, gentle friends; I must not read it:

It is not meet you know how Caesar lov'd you, You are not wood, you are not stones, but men;

${ }^{47}$ Act 3, sc.2, 1. 140-149. 
And, being men, hearing the will of Caesar,

It will inflame you, it will make you mad.

'Tis good you know not that you are his heirs;

For if you should, O! What would come of it. ${ }^{48}$

Now the citizens insist on hearing the will. Antony delays them further saying

I fear I wrong the honorable men

Whose daggers have stabb’d Caesar; I do fear it. ${ }^{49}$

With the "honorable men" standing in the way of their hearing the will that gives them a part of Caesar's fortune, the crowd erupts:

Fourth Cit: They were traitors: honorable men!

Citizens: The will! The testament!

Sec. Cit.: They were villains, murderers. The will! read the will..$^{50}$

Here Antony hears what is music to an advocate's ears: the audience of citizens itself utters the desired conclusion, that the conspirators were traitors, and their deed murder. Antony has not told them this. He has shown them the evidence, and led them to reach the conclusion on

\footnotetext{
${ }^{48}$ Act 3, sc.2, 1. 152-158.

${ }^{49}$ Act3, sc. 2 ,1. 163-164.

${ }^{50}$ Act 3, sc.2, 1. 165-167.
} 
their own. He understands that an audience will hold more strongly to a conclusion it reaches by itself.

\section{Rebuttal to expected arguments of the opposition}

Advocacy requires thinking about the likely opposition to one’s position. Antony tires to inoculate the crowd against future statements by Brutus and his group:

Good friends, sweet friends, let me not stir you up

To such a sudden flood of mutiny.

They that have done this deed are honorable;

What private griefs they have, alas! I know not,

That made them do it; they are wise and honorable,

And will, no doubt, with reasons answer you.

I come not, friends, to steal away your hearts:

I am no orator, as Brutus is;

But, as you know me all, a plain blunt man,

That love my friend; and that they know full well

That gave me public leave to speak of him. ${ }^{51}$

Antony prepares the crowd to reject-or better yet, to refuse to hear-whatever reasons Brutus and his allies may later try to offer in defense of the slaying. The "honorable" men have

${ }^{51}$ Act 3, sc.2, 1. 222-232. 
"private griefs" against Caesar, not concerns for their country. They'll have reasons, and will employ Brutus’ oratorical powers to induce the citizens to accept them, rather than stick with the plain blunt truth offered by Antony.

Antony addresses an important question in advocacy, i.e., how to deal with anticipated efforts of an adversary to refute one's case. Antony suggests to the audience that it be wary of anything offered by the opposition. He does not state the likely reasons they'll be given, but undermines any rebuttal that they might hear by suggesting first, that any reason is just the product of personal grievances and not the public interest; and second, that Brutus will try to make his case by the suspect arts of oratory, rather than by the plain truth of the matter.

This works for Antony, who is so able to arouse the crowd emotionally that he does not have to worry about its listening to reasoned argument; after his speech, the people have no desire to engage in rational discussion (as dramatically evidenced by the next scene in the play, in which Cinna the poet is attacked because he has the same name as Cinna the conspirator). Advocacy outside the no-holds-barred political arena may require a more carefully plotted plan for de-sensitizing the audience to expected adversarial rebuttal, one that may include a spelling out, with some degree of detail, of the adversary's expected reply and an analysis of its flaws.

\section{Rhetorical style}

Some of Antony's rhetorical techniques have been mentioned above, such as his use of 
the ironic refrain about his respect for the "honorable men" who claimed Caesar was ambitious. Later in the speech they are referred to as "the honorable men whose daggers stabb'd Caesar." By turning the crowd's attention to the violent killing, Antony leads the crowd to conclude that the word "honorable" loses all meaning when applied to this dishonorable act.

Antony knows the skilled orator is distrusted by those who perceive the verbal arts being employed to lead and control them. He therefore takes pains to deny using any rhetorical art. He is a plain-speaking man, he says, using mostly monosyllabic words to reinforce this claim:

I am no orator as Brutus is;

But, as you know me all, a plain, blunt man, That love my friend; and that they know full well That gave me public leave to speak of him.

Brutus, the supposed rhetorical magician, cannot be trusted. Antony, by contrast, claims not to create a clever argument-he merely puts forth facts that the people themselves know to be true:

I tell you that which you yourselves do know, Show you sweet Caesar's wounds, poor poor dumb mouths And bid them speak for me: but were I Brutus, And Brutus Antony, there were an Antony 
Would ruffle up your spirits, and put a tongue

In every wound of Caesar, that should move

The stones of Rome to rise and mutiny. ${ }^{52}$

Antony denies his own oratorical gifts even as he employs them, drawing an unforgettable metaphor comparing the wounds inflicted on Caesar to mouths unable to speak. Ironically, the wounds provide the most moving evidence of the crime Antony is prosecuting, and so they are able to "speak" for Antony most eloquently. Again ironically, Antony imagines himself rhetorically switching places with Brutus to become eloquent, and with his newfound oratorical skill suggests the case for mutiny is so strong the very stones of Rome should rise up in rebellion. ${ }^{53}$ All this is done with the clarity and grace that marks the whole speech, and places it at the highest level of rhetorical art.

Daniel Kornstein’s insightful commentary on the speeches agrees that Antony has "given a supreme example of effective persuasion” and makes this telling point in comparing the two speeches:

In comparing Brutus and Antony as orators, we are reminded of the comparison drawn between two other classical orators: Cicero and Demosthenes. When Cicero finished an oration, the people would say, “How well he spoke.” But when Demosthenes finished

${ }^{52}$ Act 3, sc.2, 1. 236-243.

53 The word "stones” may have a special resonance with this audience. Early in the play, two tribunes speak disdainfully to several commoners, labeling them "You blocks, you stones, you worse than senseless things!” Act 1, sc. 1. Antony refers to "stones" again when he says to the people, "You are not wood, you are not stones, but men.” 
speaking, the people would say, "Let us march.” Brutus was like Cicero, and Antony like Demosthenes. Brutus won respect, but Antony started a riot. ${ }^{54}$

Antony pays attention to his audience, interacts with them, and understands how to move them. He builds a rapport so strong that, late in the speech, one citizen calls out "we'll hear him, we'll follow him, we'll die with him.” No advocate could hope to wrest a greater commitment from his audience than this.

\section{$\underline{\text { Art, law and politics }}$}

The speeches of Brutus and Antony inspire some sobering thoughts on the connection of art to our law and politics. Rhetorical artistry magnifies a speaker's ability to lead listeners to a desired conclusion, to enlist an audience in a cause, and to move them to decisive action. Stirring words are long remembered, often cited, and much admired. ${ }^{55}$

But rhetorical artistry does not necessarily serve truth, fairness, justice, or other valued ends in our legal and political systems. Both our law and our politics are fueled by advocacy.

${ }^{54}$ Daniel Kornstein, Kill All the LAWYERs? SHAKESPEARE’s LEgAL APPEAL 113 (1994).

${ }^{55}$ For a case study of stirring rhetoric and goal-oriented advocacy, see Wills, Lincoln at Gettysburg, analyzing Lincoln's famous battlefield address as canny advocacy of the notion that the civil war was being fought to advance freedom, rather than simply to preserve the Union. The brief speech defied Lincoln's prediction that the world would "little note nor long remember what we say here.” 
Democratic political life depends upon the free exchange of contested ideas among many speakers and diverse audiences of citizens. The judiciary has protected that free exchange, even if it allows the introduction of odious arguments into the public debate. A fair legal system, too, depends upon the open contest of argument and counter argument by legal adversaries before audiences of juries and judges. The hope is that truth and justice will win out in the contest of competing arguments in the political arena and in the courtroom. ${ }^{56}$

Whether truth emerges from well wrought rhetorical presentations is a matter that has been a subject of serious question since the beginnings of Western civilization. Plato questioned the likelihood of truth and justice triumphing in the law courts of ancient Greece. In his dialogue between Socrates and Phaedrus, Plato writes:

Socrates: The fact is, as we said at the beginning of our discussion, that the aspiring speaker needs no knowledge of the truth about what is right or good... In courts of justice no attention is paid whatever to the truth about such topics; all that matters is

${ }^{56}$ Justice Holmes set forth the idea best for the political realm: "But when men have realized that time has upset many fighting faiths, they may come to believe even more than they believe the very foundations of their own conduct that the ultimate good desired is better reached by free trade in ideas--that the best test of truth is the power of the thought to get itself accepted in the competition of the market, and that truth is the only ground upon which their wishes safely can be carried out. That at any rate is the theory of our Constitution.” Abrams v. U.S., 250 U.S. 616, 630 (1919) (dissenting). For the legal arena, Judge Frank wrote that many lawyers "think that the best way for a court to discover the facts in a suit is to have each side strive as hard as it can, in a keenly partisan spirit, to bring to the court's attention the evidence favorable to that side.” Jerome Frank, Courts On Trial 80 (1949). 
plausibility... There are even some occasions when both prosecution and defense should positively suppress the facts in favor of probability, if the facts are improbable. Never mind the truth -- pursue probability through thick and thin in every kind of speech; the whole secret of the art of speaking lies in consistent adherence to this principle. Phaedrus: That is what those who claim to be professional teachers of rhetoric actually say, Socrates.

In the twentieth century, preeminent American scholars and judges continued to critically examine the fidelity of the legal system to truth and justice. In 1906, Roscoe Pound decried the "sporting theory of justice" that subverted fairness and the search for truth in the adversary system, in his oft-cited speech "The Causes of Popular Dissatisfaction With the Administration of Justice. ${ }^{57}$ At mid-century, Judge Jerome Frank trenchantly criticized the many courtroom techniques lawyers employed to obscure and suppress the truth, in a book offering a bracing assessment of the legal system and its flaws. ${ }^{58}$ Frank quoted Judge Learned Hand as having once remarked: “About trials hang a suspicion of trickery and a sense of result depending upon cajolery or worse." 59

Rhetorical performances that undermine justice have frequently come to the attention of courts and bar associations, which have attempted with varying degrees of success to define and

${ }^{57} 29$ A.B.A.Rep. 395, 404-406 (1906).

${ }^{58}$ Courts on Trial (1949) (see especially ch. VI, “The Fight Theory versus The Truth Theory").

${ }^{59}$ Id. at 87 
patrol the area of inappropriate advocacy. The effort, the U.S. Supreme Court has observed, is difficult, as "the line separating acceptable from improper advocacy is not easily drawn." ${ }^{\circ 0} \mathrm{~A}$ federal prosecutor who provided the jury with his own personal opinion of the defendant's guilt clearly crossed that line, the Court found in United States v. Young, ${ }^{61}$ citing American Bar Association guidelines that state: "Expressions of personal opinion by the prosecutor are a form of unsworn, unchecked testimony and tend to exploit the influence of the prosecutor's office and undermine the objective detachment that should separate a lawyer from the cause being argued." 62

Other concerns about fairness in the legal system have led to important limits on an advocate's ability to suppress evidence and keep it from the opposing lawyer and the court. The federal rules of civil procedure introduced extensive discovery rules that compelled advocates to disclose facts in their possession before trial. In state criminal cases, such discovery is often the exception rather than the rule, but the 1963 U.S. Supreme Court decision in Brady v. Maryland ${ }^{63}$ made an important inroad on the suppression of evidence by prosecutors. The Court demanded that prosecutors turn over evidentiary material that tended to exonerate the accused, upon request of the defense. Advocates are all too willing to keep vital evidence well guarded, and in many

${ }^{60}$ U.S. v. Young, 470 US 1, 7 (1985).

${ }^{61}$ Id. The Court stated the rule violation in the case was "all too common ..”

${ }^{62}$ ABA Standards for Criminal Justice 3-5.8 (2d ed. 1980) at 3.89 (commentary).

63373 U.S. 83 (1963). 
states the rules of discovery in criminal cases allows the prosecution much leeway in doing so. Brady did not eliminate these practices, and some prosecutors have failed to scrupulously follow even Brady's limited modification of the criminal prosecutor's control over evidence needed by the defense in preparing its case. A particularly egregious example of non-compliance occurred in a case in New York where a man was convicted and jailed for seven years. He was released only after it was discovered that the Bronx district attorney had failed to disclose clearly exonerating evidence. ${ }^{64}$

Disciplinary rules have also played a prominent role in restricting effective, but unfair, rhetorical techniques. The American Bar Association's rules of professional conduct identify various obligations advocates owe to the administration of justice, including refraining from tactics such as deliberately misstating the evidence in the case, misleading the jury as to the proper inferences it might draw, inciting the prejudices or passions of the jury, and predicting the consequences of the jury's verdict. ${ }^{65}$

Rules restraining rhetoric are more easily enacted within the legal system than in the political arena. Rules of professional conduct and supervision of advocacy by the courts are noticeably absent from the public forum. This is so despite the increasing professionalization of public debate. Today, professional advocates-speechwriters, corporate and government

${ }^{64}$ Upholding the man's right to sue the city of New York, a state appellate court wrote that the lower court judge properly "excoriated" the district attorney's office. Ramos v. City of New York, 729 N.Y.S.2d 678 (1 ${ }^{\text {st }}$ Dept. 2001).

${ }^{65}$ The relevant rules are quoted in United States v. Young, supra n. . 
spokespersons, public relations "spin doctors," political advertisers, lobbyists, and others-dominate the American political realm. Political messages are crafted with public opinion polls, focus groups, sound bites, and a host of other inputs and techniques designed not to communicate with or educate the public so much as to manipulate it with mass audience appeals.

These unrestrained professional rhetoricians can profoundly influence the law through political campaigns that lead to fundamental changes in the rules governing legal disputes. The current effort to enact "tort reform" is a prime example. To convince the public to support the effort to cap tort damage awards and otherwise aid tort defendants, advocates claim that the tort system routinely encourages irresponsible plaintiffs and their greedy lawyers to bring frivolous claims. These unmeritorious claims are supposedly rewarded by juries with multimillion dollar verdicts ${ }^{66} \mathrm{~A}$ single case, like the lawsuit won against the McDonald's corporation by a woman who spilled hot coffee in her lap, is portrayed as the typical, outrageous product of the current tort system. The facts that the plaintiff suffered severe, disfiguring third degree burns akin to burns from acid, and that McDonald's had received hundreds of complaints from customers and done nothing to reduce the extraordinarily high temperatures of its coffee, are excluded from the advocates' public accounts of the case. ${ }^{67}$ In the service of political advocacy, the litigation is grossly distorted, its facts misleadingly told, and its plaintiff unfairly maligned.

${ }^{66}$ The campaign is described in meticulous detail in William Haltom and Michael McCann, Distorting the Law: Politics, Media, and the Litigation Crisis (2004).

${ }^{67}$ Id. at $183-226$. 
Our legal and political systems, for better or worse, rely on the art of rhetorical performance. Lawyers, although professional advocates, are often poorly trained in rhetoric; given the potential for a brilliant rhetorician (i.e., a legal Antony) to do mischief, this may not be altogether bad. However sophisticated in rhetoric our advocates become, the ultimate problem that remains may be the one Antony adverted to-that there are too few "honorable men" among the multitude of legal and political advocates plying their trade in our country today.

\section{CONCLUSION}

Modern day advocates can profit from a study of the speeches of Brutus and Antony, as created by Shakespeare in Julius Caesar. One speech is a model of rhetorical art, yet steeped in deceit; the other is a flawed but (temporarily) successful effort to persuade the Roman citizens of the necessity for political assassination. By examining the way each speaker relates to his audience, crafts his appeals, and communicates his central points, the careful reader can learn much about the essential elements of advocacy. This does not mean that advocacy will become more ethical, however. Honest advocacy depends upon the existence of honorable practitioners. Unfortunately, there is evidence that those employing the arts of rhetoric today are often less than honorable. 